\title{
Unusual cause of lymphangitis in a 2-year-old boy
}

\author{
Rhian Morgan, ${ }^{1}$ James Teh, ${ }^{2}$ Janet Craze, ${ }^{1}$ Manish Sadarangani ${ }^{3}$
}

${ }^{1}$ Department of General Paediatrics, Oxford University Hospitals NHS Foundation Trust, Oxford, Oxfordshire, UK ${ }^{2}$ Department of Radiology, Oxford University Hospitals NHS Foundation Trust, Oxford, Oxfordshire, UK

${ }^{3}$ Department of Paediatrics, University of Oxford, Oxford, UK

\section{Correspondence to} Dr Manish Sadarangani, manish.sadarangani@ paediatrics.ox.ac.uk

Accepted 10 April 2016

\section{DESCRIPTION}

A 2-year-old previously healthy boy presented with $24 \mathrm{~h}$ of fever, and painful right axillary and elbow swelling. He had a $2 \times 2 \times 2.5 \mathrm{~cm}$ non-tender, non-erythaematous, mobile axillary mass, oedema and mild erythaema of his lower right arm, and cervical and inguinal lymphadenopathy. Initial investigations showed: haemoglobin $106 \mathrm{~g} / \mathrm{L}$, white cell count $13.2 \times 10^{9} / \mathrm{L}$ and $\mathrm{C}$ reactive protein $50 \mathrm{mg} / \mathrm{L}$. Ultrasound confirmed lymphadenopathy and soft tissue oedema, and the patient was treated with oral co-amoxiclav for lymphadenitis. After 4 days, his treatment was changed to intravenous ceftriaxone due to persisting symptoms. His fever terminated on day five, and the axillary lymph node decreased slightly in size. The arm swelling remained, so oral clindamycin was added, with little further improvement. A number of investigations were planned to investigate the persisting swelling, including lymph node biopsy, but an MRI scan (figure 1) was diagnostic-it showed cellulitis, and epitrochlear and axillary lymphadenopathy, suggestive of cat scratch disease, due to the marked inflammation around the lymph node. ${ }^{1}$ Additional history revealed the family had two cats, including one kitten. The child was treated with azithromycin for 5 days. His Bartonella henslae IgG titre was 256, confirming the diagnosis. He made a full recovery.
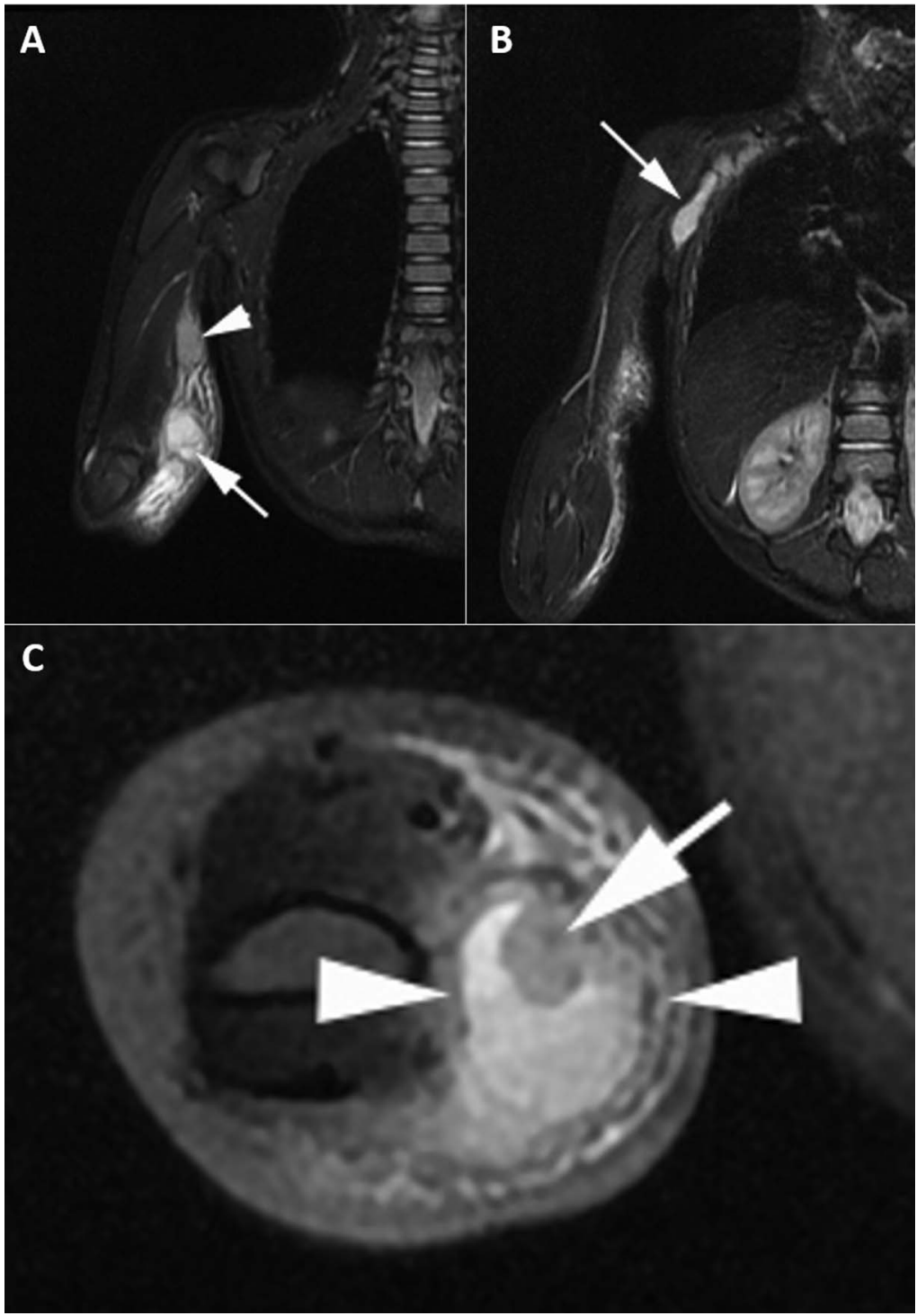

Figure 1 MRI scan of right upper arm. Coronal short tau inversion recovery demonstrating (A) a high T2 signal ovoid subcutaneous mass in the epitrochlear region (arrow), with a further mass lying more proximally (arrowhead) and (B) a sausage shaped high T2 signal mass in the right axilla (arrow). Axial T2 fat-saturated image (C) showing an ovoid subcutaneous inflammatory mass (arrowheads) with a central hilum (arrow), suggestive of a lymph node. 
Although named 'cat scratch disease', the organism can be transmitted from cats (kittens pose the highest risk) or dogs by a scratch, bite or lick, although a specific history of these is often absent. ${ }^{2}$

\section{Learning points}

- This case demonstrates the importance of obtaining full details of all potential infectious exposures including pets, and conducting a thorough examination, including of the epitrochlear lymph nodes.

- It is important to consider and specify Bartonella infection as a potential diagnosis on radiological request, so signs of this can be specifically assessed by the radiologist.

- The UK national reference laboratory ceased performing Bartonella serology in July 2015 (although PCR testing remains available from tissue samples), increasing the importance of clinical suspicion and radiological diagnosis.
Azithromycin is the only antibiotic proven to reduce duration of disease, although resolution usually occurs without treatment. ${ }^{3}$

Contributors RM was involved in clinical care of the patient, interpreted the data and drafted the initial manuscript. JT conceptualised the report, and analysed and interpreted the data. JC conceptualised the report and was involved in clinical care of the patient. MS conceptualised the report, was involved in clinical care of the patient and interpreted the data. All the authors reviewed and approved the final manuscript as submitted.

Competing interests None declared.

Patient consent Obtained.

Provenance and peer review Not commissioned; externally peer reviewed.

\section{REFERENCES}

1 Dong PR, Seeger LL, Yao L, et al. Uncomplicated cat-scratch disease: findings at CT, MR imaging, and radiography. Radiology 1995;195:837-9.

2 English R. Cat-scratch disease. Pediatr Rev 2006;27:123-8; quiz 8.

3 Bass JW, Freitas BC, Freitas AD, et al. Prospective randomized double blind placebo-controlled evaluation of azithromycin for treatment of cat-scratch disease. Pediatr Infect Dis J 1998;17:447-52.

Copyright 2016 BMJ Publishing Group. All rights reserved. For permission to reuse any of this content visit http://group.bmj.com/group/rights-licensing/permissions.

BMJ Case Report Fellows may re-use this article for personal use and teaching without any further permission.

Become a Fellow of BMJ Case Reports today and you can:

- Submit as many cases as you like

- Enjoy fast sympathetic peer review and rapid publication of accepted articles

- Access all the published articles

- Re-use any of the published material for personal use and teaching without further permission

For information on Institutional Fellowships contact consortiasales@bmjgroup.com

Visit casereports.bmj.com for more articles like this and to become a Fellow 